\title{
引抜き力をうけるアンカーボルトの応力伝達機構の解析 FAILURE MECHANISM OF ANCHOR BOLTS SUBJECT TO TENSION
}

\author{
近藤 吾 郎*, 森田司 郎** \\ Goro KONDO and Shiro MORITA
}

\begin{abstract}
Experimental and analytical studies were performed to investigate the failure mechanism of headed anchor bolts subjected to tension.

In the experiments, three bearing rings were prepared to examine the influence of the apex angle of concrete cone, which would be pulled out. The bolt displacement, the crack development and the circumferential strain on concrete surface were measured for each specimen.

In the analysis, an axisymmetric finite element method was applied to these specimens. Analytical results showed good agreement with the experimental observations.

From the experimental and analytical results, the failure mechanism of the each type of anchor bolts including the pull-out test type was clarified.
\end{abstract}

Keywords : concrete, anchor bolt, crack, pull-out test, finite element analysis コンクリート, アンカーボルト，ひび割れ，引抜き試験, 有限要素解析

\section{1. 序}

アンカーボルトは, コンクリート系構造物への機器・ 配管の据付けやプレキャスト部材の接命, 鉄骨造建築物 の柱脚部の固定など，ファスニング技術として広く利用 され,構造上重要な部位に用いられることも少なくない。 引張力を受ける頭付きアンカーボルトについては，側面 かぶりが十分な場合にはボルト自体の降伏か定着域コン クリートのコーン状破壊のいずれかによってその耐力は 決まることになる。特に耐震上重要なアンカーボルトは， 勒性を確保するため，ボルト自体の降伏で耐力が決まる ように設計を行うことが望まれるが，図一1(a) に示す ような定着域コンクリートのコーン状破壊については, 破壊機構が明確にされておらす，その耐力を支配する材 料特性についても明らかにされていない。たとえば，現 行の設計式 ${ }^{1), 2}$ )では, $\sqrt{F_{c}}\left(F_{c}\right.$ はコンクリートの設計規 準強度) が材料特性値として考慮されているが, 実際に 耐力を支配しているメカニズムや材料特性を反映するも のでない。

方, 構造体コンクリートの圧縮強度の非破壊試験法 の一つである引抜き試験法が，1980 年代に入って実用 化が進められている3!,4)。この試験法は，図一1(b) のよ うに反力を所定の位置に与えてコーン状破壊曲面を強制
したアンカーボルトの引抜き耐力がコンクリートの王縮 強度とほほ線形関係にあるという実験的事実を利用した ものであるが，ここにおいても破壊機構の解明が遅れて いるため, 試験法の物理的意味付けが確立されないでい る。

このような状況から, 近年, コーン状破壊の機構を解
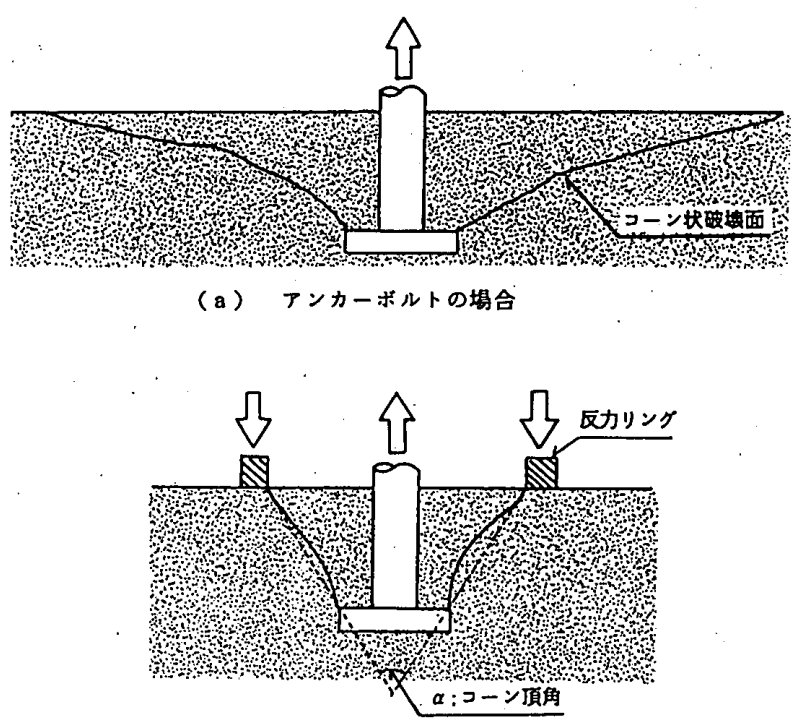

（b）引抜き㢦釦の場合.

図一1・.コーン状破壊

本研究の一部は, ”昭和 63 年度ならびに昭和 64 年度本学会大会にて発丧した。

* 京都大学工学部建築学科 助手. 工修 Research Assoc., Dept. of Architecture, Faculty of Engineering,

** 京都大学工学部建築学科 教授. 工博 Kyoto Univ., M. Eng.

Prof., Dept. of Architecture, Faculty of Engineering, Kyoto' Univ., Dr. Eng. 
明しようとする試みが，有限要素法などの解析的手法を 利用して多く行われるようになっだ51,6!。

筆者らは引抜き試験法の構造体コンクリート強度試験 法としての有効性に注目し，その強度特性に関係する影 響因子として, 粗骨材量や乾湿の引抜き強度に対する影 響についての評価を実験的に行ってきたが光，既往の解 析的研究によって導かれた破壊機構ではその実験結果を 明確に説明できなかった。

本研究は, 図一1の (a) から (b) の範囲で反力の作 用する位置が異なるアンカーボルトのコーン状破壊機構 を解明し，耐力の決定要因となる材料特性を明らかにす ることを目的とするものである。具体的には，まず半無 限とみなせるコンクリートに定着されたアンカーボルト の引抜き実験を反力位置を変化させて行い，次にそれら の供試体について有限要素解析手法を用いたシミュレー ションを行った。

コンクリート構造物に対する有限要素解析の適用は, 多くの研究者により行われているが，そのほとんどは平 面応力問題であり，立体解析への適用を行った例は少な かった。近年になって, 解析精度の向上を目的として, コンクリートの材料特性を精密にモデル化した材料構成 関係の開発が行われている。本研究では，これらの研究 成果を反映した材料モデルを用い，その適用性について も検討した。

\section{2. 実験内容}

2.1 供試体

アンカーボルトの埋め込み部詳細と供試体形状を図一 2 に示す。供試体側面および底面には載荷後供試体を割 裂し内部のひび割れ状況を観察するためのノッチを設け た。アンカーボルトは，M20の高力ボルトで，その定 着部には直径 $50 \mathrm{~mm}$ 厚 $9 \mathrm{~mm}$ の定着プレートを埋め込 み深さを $50 \mathrm{~mm}$ となるように型枠に取り付けた。コン クリート打設は，ボルト軸が水平となるような姿勢で, すなわち，図一2(b) 下図の状態で行った。

供試体一覽を表一1 に示す。実験変数は, 反力の作用 位置とし，所定の内径を持つ鋼製リングを反力受けとし て用いることにより変化させた。反カリングの内周と定 着プレート外周を結んだ円錐台の頂角 $\alpha$ を用いて表す と, 反カリングの内径が, $116,160,450 \mathrm{~mm}$ の場合, それぞれ $\alpha=67,95,152^{\circ}$ となる。以後反力の作用位置 は，この頂角 $\alpha$ を用いて表す。

LC, MC, NC, NM の各シリーズは, 同一バッチの コンクリートからそれぞれ 4 体を作製し，これら 4 体の 内 1 体は最大耐力以降完全にボルトが抜きでるまで加力 を行い，残りの 3 体は内部ひび割れの進展状況を調査す るため最大耐力に達する前に加力を終了した。なお, 内 部ひび割れ観察の荷重レベルは, 最大耐力の約 60，75,
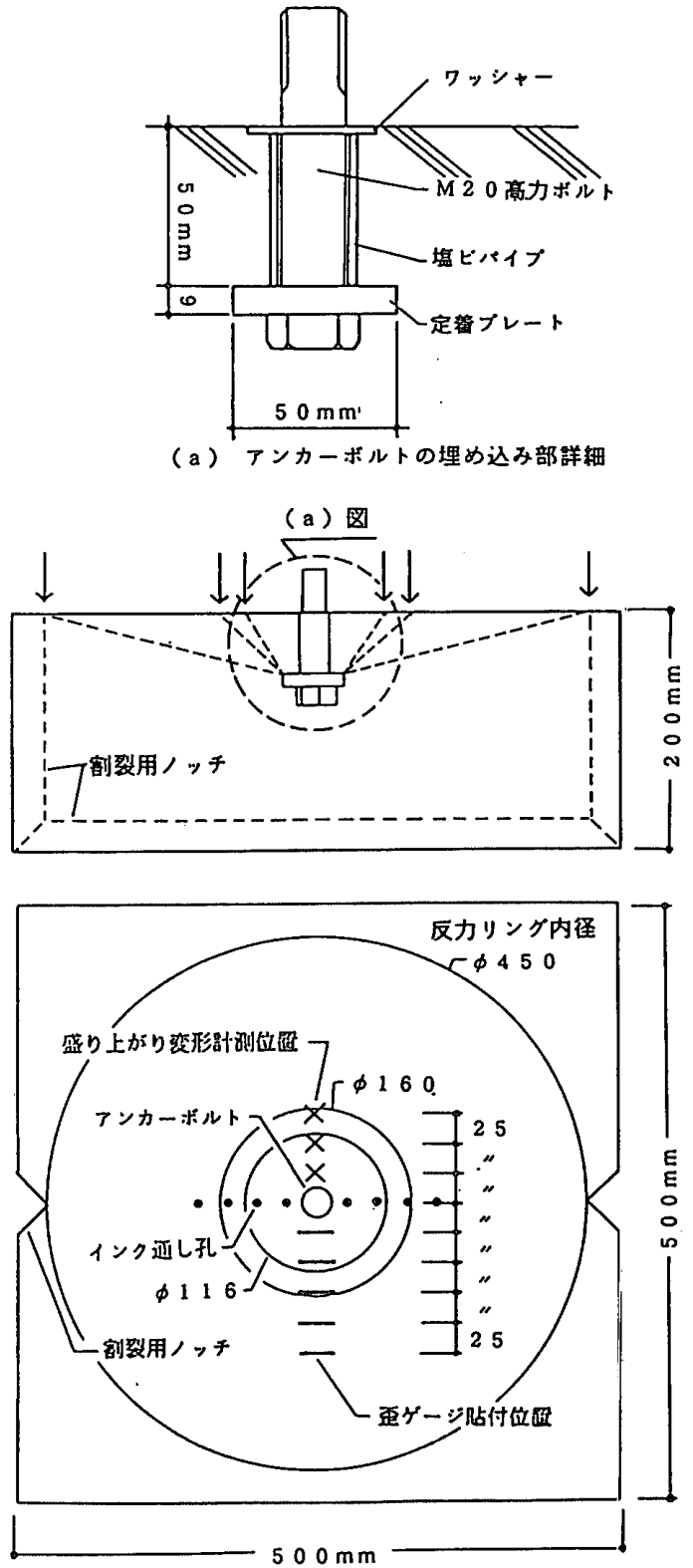

(b) 供式体形状

図一2 供試体

表一1 供試体一覧

\begin{tabular}{|c|c|c|c|c|}
\hline シリーズ & 䟼倹体数 & 反カリング得 & ユーン頂角； $\alpha$ & 骨材最大粹理 \\
\hline $\begin{array}{l}\text { LC } \\
\mathrm{MC} \\
\mathrm{NC}\end{array}$ & $\begin{array}{l}4 \\
4 \\
4\end{array}$ & $\begin{array}{l}450 \mathrm{~mm} \\
160 \mathrm{~mm} \\
116 \mathrm{~mm}\end{array}$ & $\begin{array}{r}152^{\circ} \\
95^{\circ} \\
67^{\circ}\end{array}$ & $\begin{array}{l}20 \mathrm{~mm} \\
20 \mathrm{~mm} \\
20 \mathrm{~mm}\end{array}$ \\
\hline NM & 4 & $116 \mathrm{~mm}$ & $67^{\circ}$ & $5 \mathrm{~mm}$ \\
\hline S C & 3 & $\begin{array}{l}450 \mathrm{~mm} \\
160 \mathrm{~mm} \\
116 \mathrm{~mm}\end{array}$ & $\begin{array}{r}152^{\circ} \\
95^{\circ} \\
67^{\circ}\end{array}$ & $20 \mathrm{~mm}$ \\
\hline
\end{tabular}

$90 \%$ の 3 レベルとした。また, 反力位置の変化がコー ン状破壊耐力に与える影響を直接調查するため，SC シ リーズとして同一バッチのコンクリートから 3 体作製 し，反力位置を変化させた引抜き実験を行っだ。

$\mathrm{NM}$ シリーズは, 引抜き試験において対象とするコ ンクリートの粗骨材の最大粒径や粒骨材量により引抜き 耐力が変化するという実験結果を確認するためのもの 
表一2 コンクリートの調合

\begin{tabular}{|c|c|c|c|c|c|}
\hline \multirow{2}{*}{ シリース } & \multicolumn{4}{|c|}{ 単位重量， $\mathrm{k} \mathrm{g} / \mathrm{m}^{*}$} & \multirow{2}{*}{ 俑 考 } \\
\hline & セメント & 水 & 梱骨材 & 柤骨材 & \\
\hline LC, MC,NC, SC & 308 & 185 & 888 & 908 & \multirow{2}{*}{ A E 敖 $1.5 \%$ 添加 } \\
\hline NM & 484 & 315 & 1131 & --- & \\
\hline
\end{tabular}

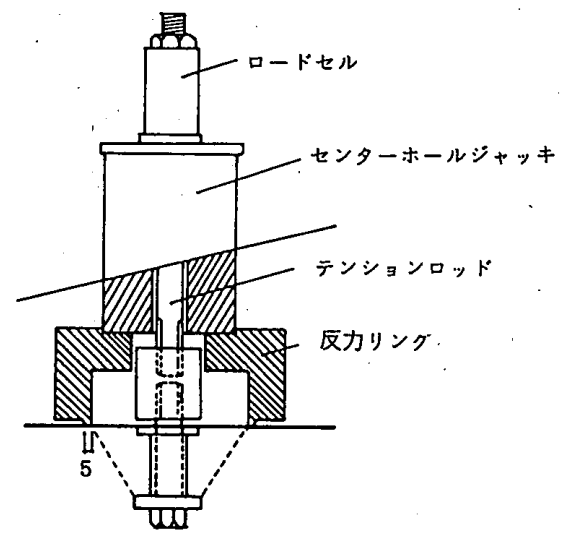

図一 3 載荷装置

で，他のシリーズに用いた骨材の最大粒径は $20 \mathrm{~mm}$ で あるのに対して NM シリーズでは最大粗骨材粒径が 5 $\mathrm{mm}$ のモルタルを用いた。

使用したコンクリートの調合を表一 2 に示す。供試体 は, 材令 2 週まで湿布養生を行い，その後は気中に放置 し十分乾燥させた。実験時の材令は，5週から 6 週であ る。

\section{2 載荷装置と測定項目}

載荷装置を図一 3 に示す。なお, 反カリングの厚さは, 荷重の増加に従って反力の重心位置が大きく変化する事 がないように $5 \mathrm{~mm}$ とした。ただし，円錐台の頂角 $\alpha=$ $152^{\circ}$ の場合には，供試体の引抜き面に直径 $450 \mathrm{~mm}$ 深さ $20 \mathrm{~mm}$ の凹部を設け, その外周コンクリート部に反力 を与えて載荷を行った。

ボルトの抜け出し量の測定は, 定着プレートの直径上 2 点に取り付けたピアノ線を供試体底面まで延長して, 供試体底面に対する相対変位として計測した。また，引 抜き表面の盛り上がり変形も同様に底面に対する変位を 図一2(b) 中に示した点で測定した。

また，図一2(b) 中に示した小孔にインクを注入した 状態で内部ひび割れ調查荷重まで載荷し，載荷終了後供 試体側面および底面に設けたノッチに沿って割裂し，そ の割裂面に表れたコーン状ひび割れの進展状況を実体顕 微鏡を用いて観察した。さらにボルト軸から半径方向に 発生するひび割れ状況は, 載荷後の顕微鏡による観察に 加え, 図一2(b) 中に示した位置に貼付したゲージ長 30 $\mathrm{mm}$ の表面ひずみゲージによりリング方向のひずみを計 測した結果を参考にして判断した。
表一3 実験結果一筧

\begin{tabular}{|c|c|c|c|c|c|c|}
\hline \multirow{2}{*}{ シリーズ } & \multirow{2}{*}{$\begin{array}{c}f \mathrm{c} \\
\mathrm{kgf} / \mathrm{cm}^{2}\end{array}$} & \multirow{2}{*}{$\begin{array}{c}\mathrm{f} \dot{\mathrm{t}} \\
\mathrm{kgf} / \mathrm{cm}^{2}\end{array}$} & \multicolumn{3}{|c|}{ ひび割れ溒查荷重 tonf } & \multirow{2}{*}{$\frac{\text { 最大耐力 }}{4}$} \\
\hline & & & 1 & 2 & 3 & \\
\hline L C & 278 & 28.0 & 2. 0 & 2. 5 & 3. 0 & 3. 1 \\
\hline $\mathrm{MC}$ & 262 & 28.6 & 3. 8 & 4. 5 & 5. 5 & 6. 2 \\
\hline $\mathrm{NC}$ & 261 & 26.6 & 4. 0 & 5. 0 & 6. 1 & 7. 1 \\
\hline $\mathrm{NM}$ & 287 & 28.5 & 2. 0 & 4. 0 & 5. 0 & 6. 1 \\
\hline
\end{tabular}

\begin{tabular}{|c|c|c|c|c|c|}
\hline \multirow{2}{*}{ シリース } & \multirow{2}{*}{$\mathrm{f}$} & $\mathrm{f} \mathrm{t}$ & \multicolumn{3}{|c|}{ 大耐力 tonf } \\
\cline { 5 - 8 } & $\mathrm{kgf} / \mathrm{cm}^{2}$ & $\mathrm{kgf} / \mathrm{cm}^{\circ}$ & $\begin{array}{c}\alpha= \\
152^{\circ}\end{array}$ & $\begin{array}{c}\alpha= \\
95^{\circ}\end{array}$ & $\begin{array}{l}\alpha= \\
67^{\circ}\end{array}$ \\
\hline $\mathrm{SC}$ & 247 & 25.5 & 3.7 & 6.0 & 6.4 \\
\hline
\end{tabular}

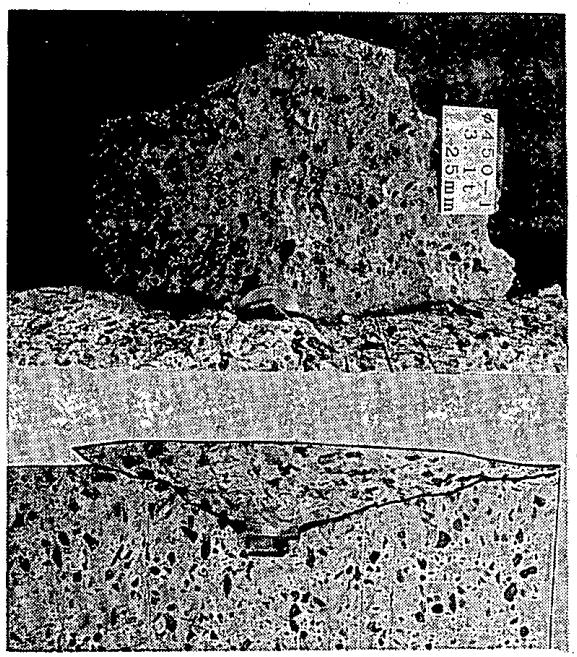

写真一1 コーン状破壊状況 (LC)

\section{3. 実験結果の概要（破壊モードと破壊耐力）}

実験結果の一覧を，表一 3 に示す。破壊まで加力した 供試体は、すべてコーン状破壊であった。写真一1にコー ン状破壊の状況を示す。円錐台頂角 $\alpha=152^{\circ}$ の場合, 最 大耐力以降徐々に耐力を失うのに対し， $\alpha=96,67^{\circ}$ では, 最大耐力後急激に耐力を失い脆性的にコーンが抜け出る 破壊であるという違いがあった。抜け出たコーンの形状 は， $\alpha=152^{\circ}$ の場合定着プレート付近ではコーン頂角が $120^{\circ}$ 前後で, 引抜き表面に近づくに従ってその角度を 增し表面付近ではほぼ表面に平行に広がっているのが特 徵である。しかしこの引抜き表面では、コーン破壊面は 反力位置にまで達していないことから, 反力位置のコー ン破壊面形状に与える影響はなかったと考えられる。 $\alpha$ $=96,67^{\circ}$ の場合は, 共にコーンの形状は側面内側に凹 な円錐台で，引抜き表面では反カリングの寸法に等しい 円形であり, 破壊コーンの形状は反力位置によって決定 されたものであった。

計測したひずみおよび変形については, 解析結果と比 較するために, 後述する。

\section{4. コーン状破壊機構の解析}

4.1 解析対象のモデル化と解析手法

解析は, LC, MC, NC 各シリーズの供試体につい て有限要素法を用いて行った。供試体は, 図一4に示す 
ように軸対称と見なし，節点数は 636（1 272 自 由度), 要素数 1152 に要素分割した。要素には, 鋼・コンクリート共に 3 節点 3 角形要素を用 い, 要素内のひずみは要素重心位置の值で一定 とした。加力は, ボルト軸部では 1 軸引張応力 状態であると仮定して図一4 中に示したボルト ヘッドの節点に引張力を加えて行い, 材料の非 線形性に伴う不釣合力は次ステップで増分荷重 とともに解放するものとした。ただし，ひび割 れの発生による不钧合力については同じ荷重階 で収束計算を行うものとした。

ボルトヘッドと定着プレート間および定着プ レート下面の支圧面とコンクリート間では密着 しているものとした。またボルトヘッドと定着 プレート側面での付着は無視して解析モデル化 を行った。

\section{2 材料モデル}

鋼材部分は，奏験において降伏は生じなかったので弾 性とした。

コンクリートは，ひび割れ破壊までは等方性モデルと し，八面体垂直応力 $\left(\sigma_{o c t}\right)$-体積ひずみ $\left(\varepsilon_{o c t}\right)$ 関係と八面 体せん断応力 $\left(\tau_{o c t}\right)$-八面体せん断ひずみ $\left(\gamma_{o c t}\right)$ 関係は互 いに独立であるとした。

八面体垂直応力 $\left(\sigma_{o c t}\right)$-体積ひずみ $\left(\varepsilon_{o c t}\right)$ 関係は, 次に 示す Gerstle の提案 $\left.{ }^{8}\right)$ による接線体積弾性係数 $K_{t}$ を用い て表した。

$$
K_{t}= \begin{cases}K_{0} & \sigma_{o c t} \geq 0 \text { の場合 } \\ K_{0}\left(1-C_{1} \cdot \frac{\sigma_{o c t}}{f_{c}}\right) & \frac{1-C_{2}}{C_{1}} f_{c}<\sigma_{o c t}<0 \text { の場合 } \\ C_{2} \cdot K_{0} & \sigma_{o c t} \leq \frac{1-C_{2}}{C_{1}} f_{c}<0 \text { の場合 }\end{cases}
$$

ここで，係数 $C_{1} ， C_{2}$ は，それぞれ $0.5,0.2$ とする。

また，応力およびひずみの引張を正とし，圧縮強度 $f_{c}$ は負值とする。

八面体せん断応力 $\left(\tau_{o c t}\right)-八$ 面体せん断ひずみ $\left(\gamma_{o c t}\right)$ の 関係にはSargin 式")を用いて次のように表される。

$$
\frac{r_{o c t}}{r_{f}}=\frac{C_{3} \frac{\gamma_{o c t}}{\gamma_{f}}-C_{4}\left(\frac{\gamma_{o c t}}{\gamma_{f}}\right)^{2}}{1+\left(C_{3}-2\right)\left(\frac{\gamma_{o c t}}{\gamma_{f}}\right)+\left(1-C_{4}\right)\left(\frac{\gamma_{o c t}}{\gamma_{f}}\right)^{2}}
$$

ただし $\frac{\gamma_{\text {oct }}}{\gamma_{f}}>5$ の場合は 5 とする。

ここで, $C_{3}=\frac{G_{0}}{G_{f}}(\geq 2), C_{4}=0.3, G_{f}=\frac{r_{f}}{r_{0}}\left(G_{0}:\right.$ 初期 せん断弾性係数) とする。

また， $\tau_{f}$ は，破壊曲面上での八面体せん断応力を， $\gamma_{s}$ は $\tau_{f}$ に対応する八面体せん断ひずみを表す。

$\gamma_{f}$ は, 高圧縮応力下での王縮靭性を考慮して, 次式 で表した。

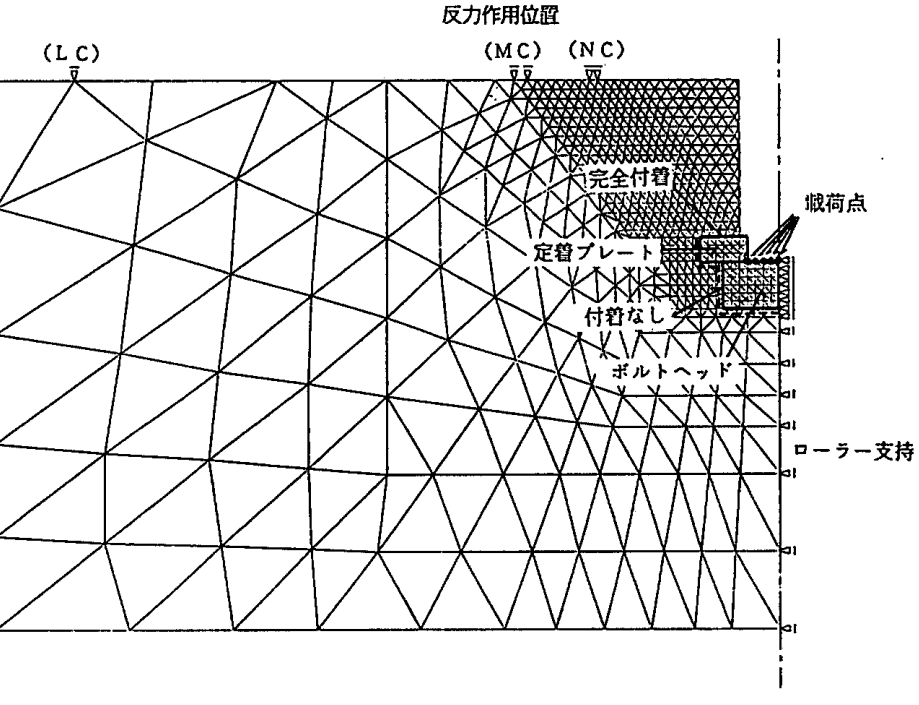

図一4 要素分割図

$$
\gamma_{s}=\gamma_{s u} \cdot\left[1+\frac{2 \sqrt{6}}{\left|f_{c}\right|}\left(r_{s}-r_{s u}\right)\right]
$$

ただし $r_{f}<r_{f u}$ の場合は, $r_{f}=r_{f u}$ とする。

ここで， $\tau_{f u}, \gamma_{f u}$ はそれぞれ一軸生縮破壊時の八面体せ ん断応力とひずみを表す。

破壊条件には，次式で表されるOttosen ${ }^{10)}$ の提案する 条件を用いた。

$$
A \frac{J_{2}}{\left|f_{c}\right|^{2}}+\lambda \frac{\sqrt{J_{2}}}{\left|f_{c}\right|}+B \frac{I_{1}}{\left|f_{c}\right|}-1=0
$$

ここで，入は偏差角 $\theta$ の関数で次式で与えられる。

$$
\lambda=\left\{\begin{array}{c}
K_{1} \cos \left[\frac{1}{3} \arccos \left(K_{2} \cos 3 \theta\right)\right] \\
\cos (3 \theta) \geq 0 \text { の場合 } \\
K_{1} \cos \left[\frac{\pi}{3}-\frac{1}{3} \arccos \left(-K_{2} \cos 3 \theta\right)\right] \\
\cos (3 \theta)<0 \text { の場合 }
\end{array}\right.
$$

ここで, $I_{1}$ は, 応力の 1 次不変量, $J_{2}, J_{3}$ は, それぞれ， 偏差応力の 2 次， 3 次の不変量を表す。

また，破壊局面の形状を決定する，係数 $A, B$ および， $K_{1}, K_{2}$ は, Schickert ${ }^{11)}$ の実験結果 $\left(f_{c}=300 \mathrm{kgf} / \mathrm{cm}^{2}\right)$ から決められる次の值を用いた。

$A=3.2244, B=3.4555, \quad K_{1}=11.1538, \quad K_{2}=0.9962$

ひび割れ破壊は，図一 5 中に示すように八面体せん断 応力が 1 軸圧縮破壊時に対応する值より小さい場合に生 じるものとした。

ひび割れの発生した後のコンクリートは直交異方性材 料とみなし，ひび割れは応力ーひずみ関係で表現する分 布ひび割れでモデル化した。分布ひび割れモデルでは， 応力状態はひび割れ面に平行方向, 直交方向の直応力成 分とひび割れ面を伝達するせん断応力成分で表される。

ひび割れに平行方向の応力成分 $\sigma_{s t}$ については, Vecchio らの研究，すなわちひび割れ間の圧縮ストラット 


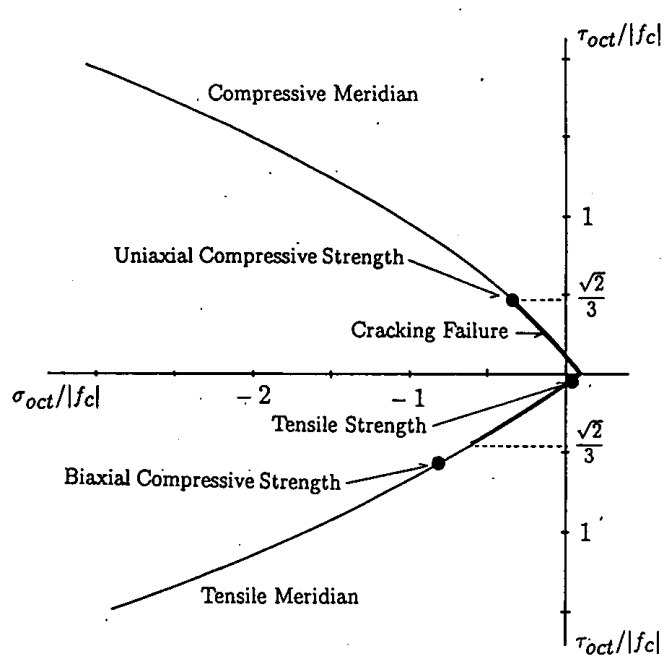

図一5 コンクリートの破壊条件

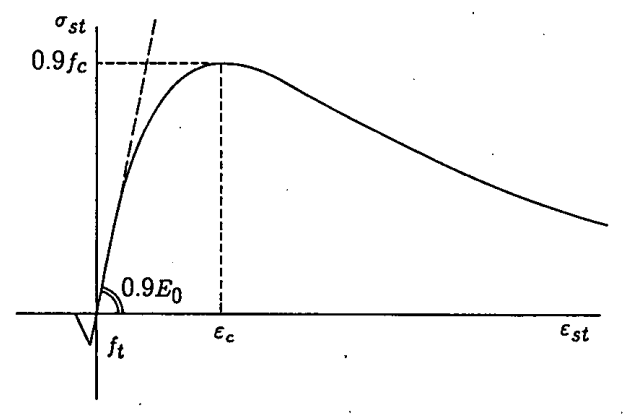

図一6 ひび割れ面に平行方向の応力ーひずみ関係

の強度は 1 軸圧縮強度 $f_{c}$ より低くなるという報告 ${ }^{12}$ 以 来,ひび割れ㨁交方向の平均ひずみの関数とした強度低 減係数が設けられることが多い。しかし本解析対象では 要素の寸法が小さく，またひび割れを横切る鉄筋の付着 応力による影響がないことから，RC平板を対象とした 既往のモデルよりは低減効果は少なく，またひび割れ幅 による影響も少なくなると考えられるため，圧縮強度の 低娍係数はひび割れ幅に関係なく 0.9 とし，ひび割れに 平行方向の応力 $\sigma_{s t}$-ひずみ $\varepsilon_{s t}$ 関係を図一 6 に示すよう に, Sargin 式 ${ }^{9)}$ で表現した。

ひび割れ面の直交方向の応力成分 $\sigma_{c r}$ については，ひ び割れ発生からひび割れ面が分離する間の引張ひずみ軟 化域に関するモデルが多く提案されているが，そのほと んどはひび割れ面の直交方向の応力をひび割れ幅で表現 したものである。本解析のように分布ひび割れで表現す る場合にこのようなモデルを適用した場合, “ひび割れに よる破壊エネルギーが要素寸法に忘じて変化するため， ひび割れの進展に影響し解析結果を左右することが報告 されている(3)。そこで, 寸法の異なる要素においても破 壊エネルギーが等価になるように，直線でモデル化した ひび割れ後の引張軟化域の勾配を図一7に示すように変 化させた。だだし，対称軸に対して放射状に生じる放射 状ひび割れについては，このような考慮は行わず，図一 7 .中の $\alpha_{s}$ を 3 とした応力ーひずみ関係で表した。

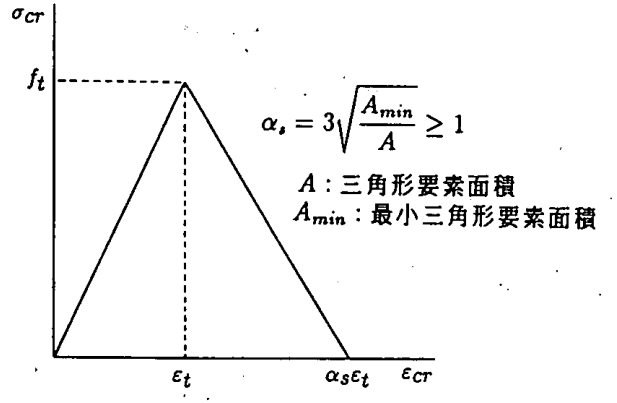

図一7 ひび割れ後の引張軟化特性

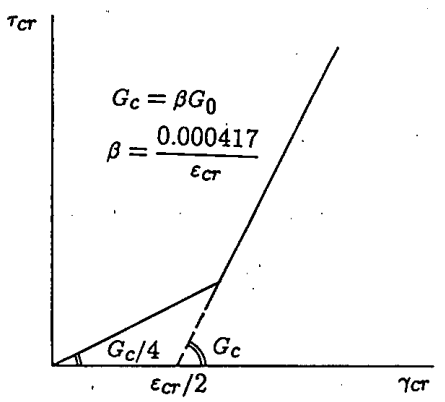

図一8ひび割れを含むコンクリートのせん断応力ーひずみ関係

表一4 材料定数

\begin{tabular}{|c|c|}
\hline \multicolumn{2}{|l|}{ 鋼材 } \\
\hline $\begin{array}{l}\text { ヤング係数 } \mathrm{ES}\left(\mathrm{kgf} / \mathrm{cm}^{2}\right) \\
\text { ポアンン比 } \nu \mathrm{s}\end{array}$ & $\begin{array}{l}21000000 \\
0.25\end{array}$ \\
\hline \multicolumn{2}{|l|}{ コンクリート } \\
\hline 初期ヤング保数 $\mathrm{EcO}\left(\mathrm{kgf} / \mathrm{cm}^{2}\right)$ & 210000 \\
\hline 初期ボアンン比 $\nu \mathrm{co}$ & 0.17 \\
\hline $\mathrm{f} \mathrm{c}\left(\mathrm{kgf} / \mathrm{cm}^{2}\right)$ & 260 \\
\hline $\mathrm{ft}\left(\mathrm{kgf} / \mathrm{cm}^{2}\right)$ & 26 \\
\hline 圧縮強度時縦雨 $\varepsilon \mathrm{c}$ & $0.25 \%$ \\
\hline
\end{tabular}

またひび割れ面のせん断伝達に関しては，ひび割れ 面における骨材の接触が不十分なせん断滑り変形が少な い段階でせん断剛性は低く, せん断滑り変形が増し十分 に骨材が接触した段階ではせん断剛性が増加するハード スプリング特性を現す。この特性を表現するため図一8 に示すようにひび割れたコンクリートのひび割れ面方向 に対するせん断応力 $\tau_{c r}$ ひずみ $\gamma_{c r}$ 関係をハードニング 型のバイリニアモデルで与えた。

\section{3 材料定数}

解析に用いた材料定数を表一 4 にまとめて示す。コン クリートについては, 実験で用いたコンクリートシリン ダーの試験結果の平均的な值とした。

\section{5. 実験結果と解析結果の比較}

\section{1 最大耐力}

解析の最大耐力は, 0.1 tonf の增分荷重を与え, 解が 発散する直前の荷重としたが，LC，MC， NCそれぞ れ 3.7，6.0，7.0 tonfであった。実験および解析から得 られたコーン頂角の違いによる最大耐力の変化を図一 9 


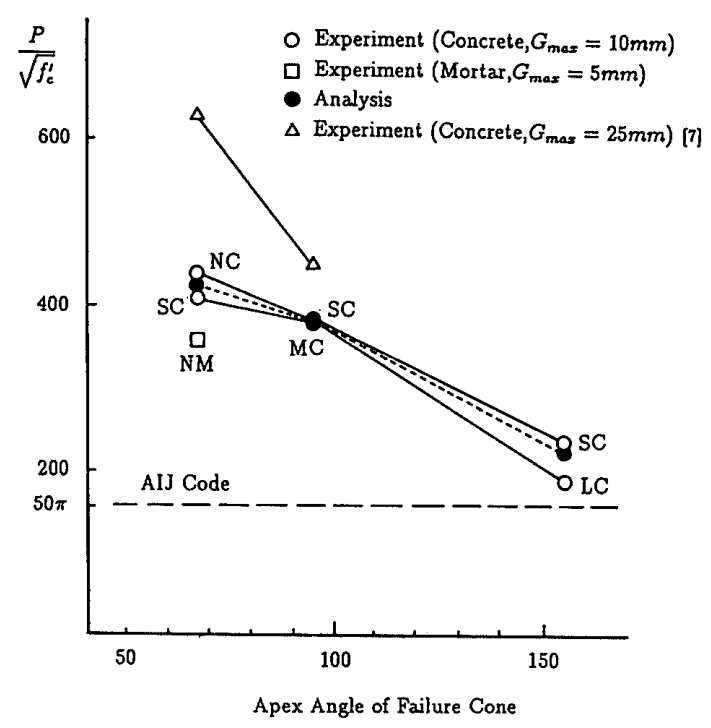

図一9コーン頂角の違いによる最大耐力の変化

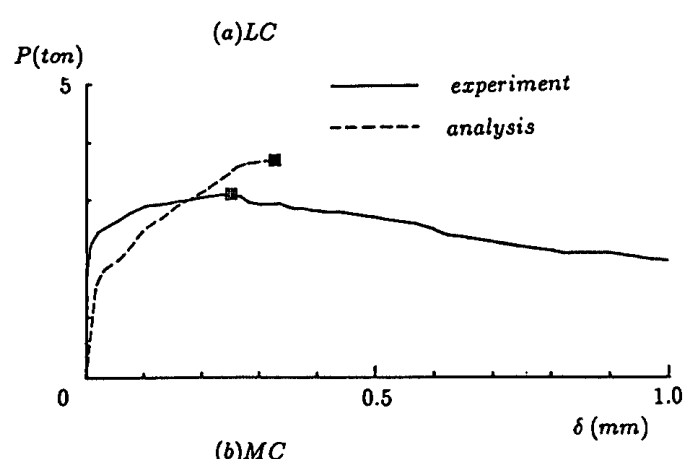

(b) $M C$

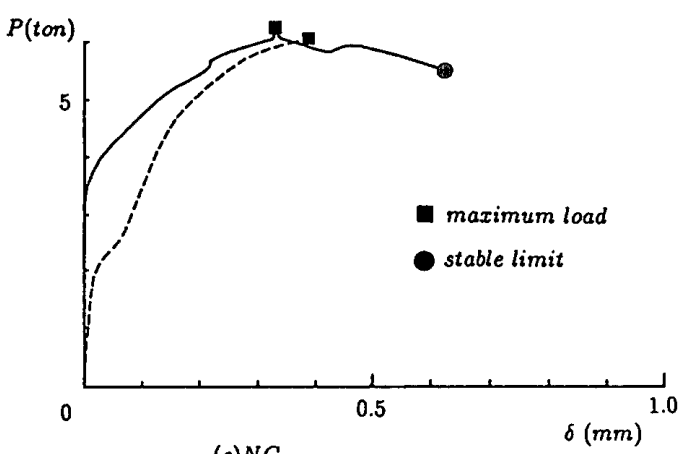

(c) NC

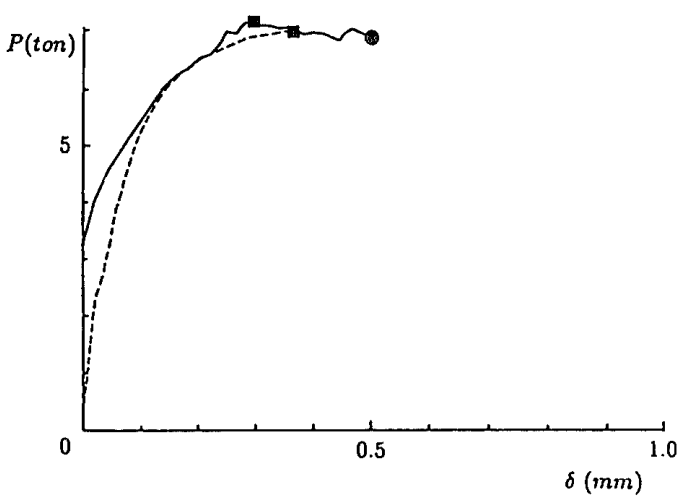

図一10 引抜き荷重-ボルトの抜け出し変位関係

に示す。また，著者らが本実験と同一のアンカーボルト で，粗骨材の最大粒径が $25 \mathrm{~mm}$ のコンクリートを用い て行った実験結果”を併せて示した。実験時のコンク (a) LC

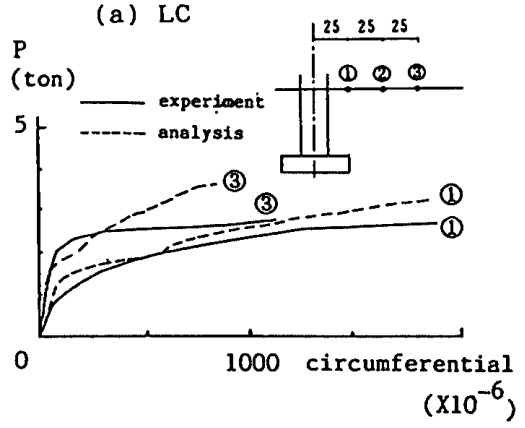

(b) MC

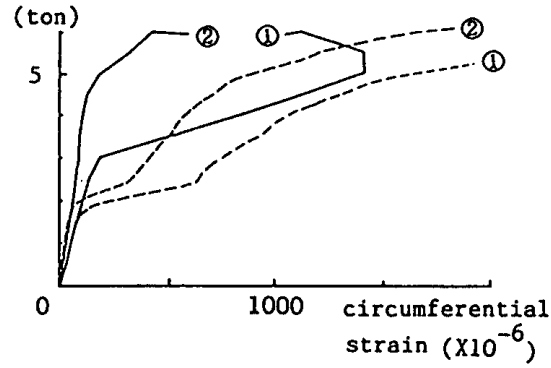

(c) NC

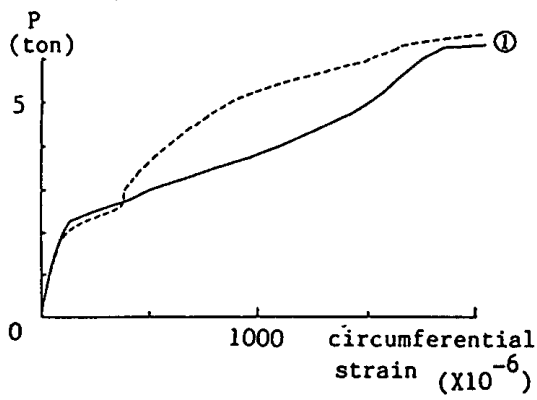

図一11引拔き荷重-リング方向のひずみ関係

リート強度の違いは，日本建築学会各種合成構造設計指 針式"を参考に $\sqrt{f_{c}}$ で補正した。

反力位置が無限遠となった状態を再現した LCでは, アンカーボルトの設計規準臫力に対応していることがわ かる。また，コーン頂角 $\alpha=67^{\circ}$ の場合，骨材の最大粒 径によって最大耐力が影響を大きく受けることがわか る。ここで採用した材料モデルを用いた解析値は，本㬰 験で得られた反力位置の違いによる最大耐力の変化の傾 向を表現している。

\section{2 荷重-ボルトの抜け出し変形関係}

図一10に奏験および解析から得られた荷重-ボルトの 抜け出し変位曲線を示す。この図より, 解析での抜け出 しは載荷初期から生じていて, 実験との差はボルトヘッ ドや定着プレートの外周面などとコンクリートとの間の 付着を無視したためであると考えられる。その結果定着 プレートからのひび割れ進展が早まり剛性低下の開始が 実験に比べ低い荷重で起こっている。しかしボルトが抜 け出すにつれてこの付着は城退するのでおおよそ良い対 応を示すようになる。ひび割れが生じ抜け出しが進行す ると，反力位置が破壊コーンに影響しない LC シリー ズと破壊コーンの形状が決定される NC ゃ MC の両シ 
(c) NC
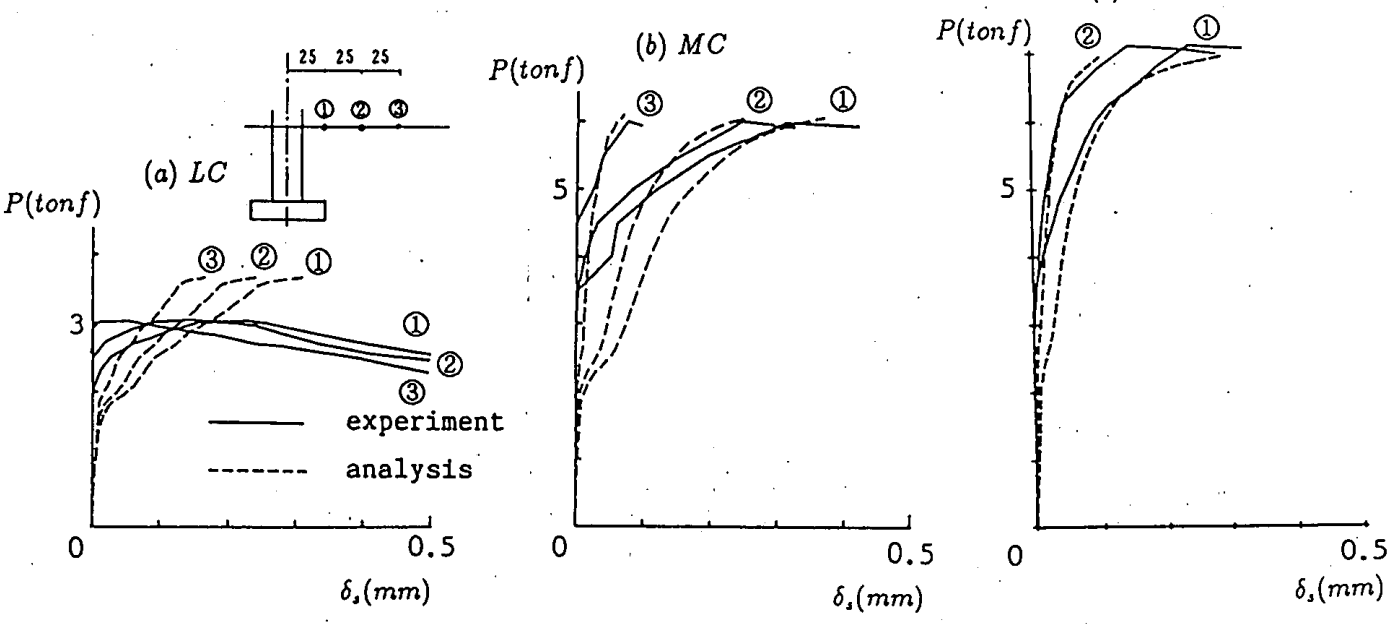

图一12 引拔き荷重と引抜き表面の面外变形の関係

リーズでは差が表れている。LCではひび割れ発生後の 剛性劣化が著しく最大耐力までの耐力の上昇がわずかで あり，最大耐力以降もなだらかに耐力を失いながら変形 が進行している。これに対し，MCやNCでは変形が 開始してからもかなりの剛性で耐力が上昇し最大耐力以 降不安定な破壊を生じている。解析でもこの傾向は表れ ているが，LCでは変形が進み始めた後の剛性が実験に 比べ大きいため, 最大耐力は解析值が高くなっている。 しかし写真でも見られるようにSC シリーズの同じ条件 での実験は，解析値とほぼ同じであり，この 2 つの実験 の耐力の差は，SCでは破壊コーンの形状が引抜き面で 大きく広がった軸対称形であったのに対して，LCでは 軸対称でなかったという破壊形式の無作為な違いによる ものと考えられる。

\section{3 荷重一㭖周方向ひずみ関係}

図一11 に実験之解析で得られた引抜き荷重と引抜き 面上のリング方向のひずみの関係を示す。このひずみは 引き抜かれるコーン内ですべて引張りであり，引抜き表 面でのコンクリートは外周方向（遠心方向）へ変形して いることがわかる。実験では,ボルトに近い(1)や(2)のデー タはリング方向以外のひずみの影響を受けやすく，離れ た(4)や(5)では非対称の変形が起こりやすいので純粋な円 周方向のひずみとはいえないが, 解析は実験の傾向をよ くとらえているといえる。解析ではすべての供試体にお いて最大耐力時には半径方向のひび割れが破壊コーンの 引抜き面上に生じていることになるが，これは実験で引 き拔かれたコーンの引抜き面全面に，反力位置に関係な く5〜7本の放射状ひび割れが生じていたことからも裏 付けられる。

\section{4 荷重-表面変形関係}

荷重と引抜き表面の面外方向への盛り上がり変形との 関係を図一12 に示す。 $\mathrm{NC}$ や $\mathrm{MC}$ では, 対称軸から離 れるのに伴って変形が小さくなり, 特に反カリング付近
では最大耐力に近づくまではほとんど変形せず，最終的 に引き抜かれるコーン破壊面が反カリングに到達するの. は最大耐力付近であることがわかる。解析での最大耐力 時の引抜き面の変形は, ほぼ実験時の特徵を再現してい る。これに対して, LC の実験結果は, 解析結果が示す ほど変形は大きくなく、特にボルト軸から離れた(3)では 最大耐力時での変形はほとんどなく，両者の対応は良く ない。

\section{5 ひび割れの進展状況}

図一13に，実験において観察されたひび割れ進展の 状況を模式的に示す。(a) 図に示す LC の場合には, 既往の報告 ${ }^{14)}$ にもあるように，荷重レベルの低い段階で は定着プレートから頂角の小さい円錐台状のひび割れが 生じ, 荷重增加に従ってこのひび割れが引抜き表面に平 行方向に向きを変えながら進展しコーン状破壊面を形成 していく。このひび割れは, 最大耐力以降も安定したま ま進展を続ける。ただし, 写真一1で示したようにこの 供試体のコーンひび割れは非対称であり，図に示さない 反対側のひび割れはこのひび割れよりもコーン頂角の小

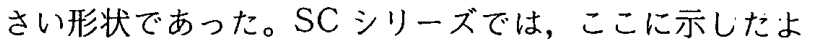
うなひび割れパターンであり，またほぼ対称であるとい えるものであった。

(b)，(c)に示す MCやNCの場合には，初ひび割れ は（a）図と同じ程度の頂角を持つ円錐台状のひび割れ であるが，これは引抜き面には到達せず，このひび割れ で形成されたコーンの内側に 2 次ひび割れが生じる。こ のひび割れも定着プレート外周と反カリング内周を結ん だ円錐台よりも内側にわずかにくぼみながら進展し， $\mathrm{MC}$ の場合反カリング方向に向かって進んでいる。引 拔き力が増加すると 2 次ひび割れの内側にさらにひび割 れが生じる。このひび割れは,他のひび割れが定着プレー トから進展するのと異なりコーン内部で発生することが 特徴である。コーン状破壊面は, $\mathrm{MC}$ の場合には 2 次 
(a) $L C(2.0 \operatorname{ton} f)$

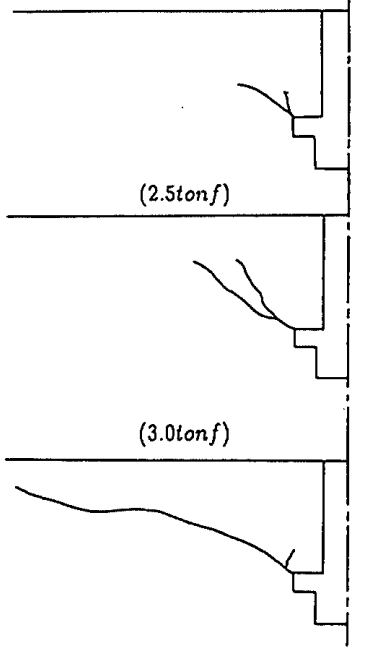

(b) $M C(3.8 \operatorname{ton} f)$

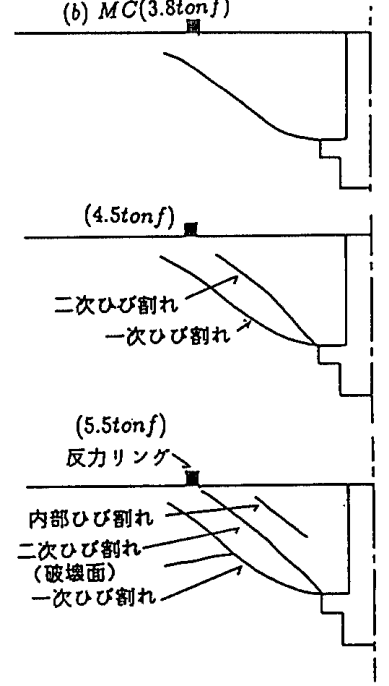

(c) $N C(4.0 \operatorname{ton} f)$

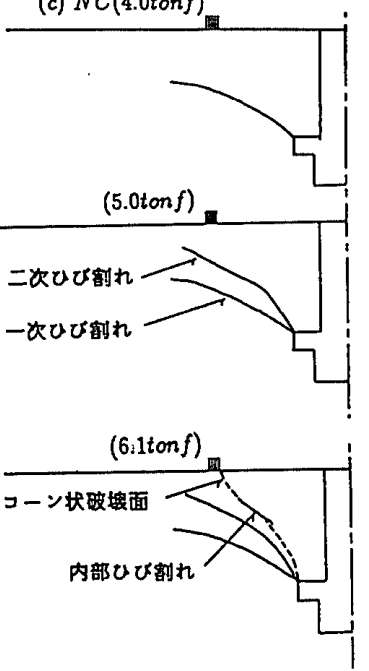

図一13ひび割れ進展の状況

(a) $L C(2.5 \operatorname{ton} f)$

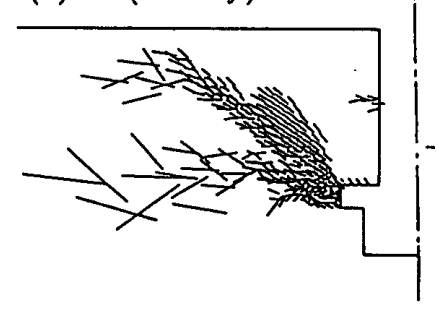

(b) $M C(4.0 \operatorname{ton} f)$

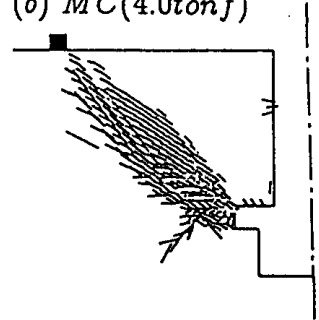

(c) $N C(5.0 \operatorname{ton} f)$

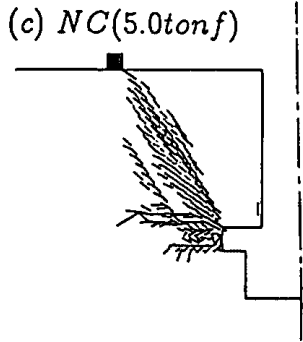

図一14ひび割れの進展状況（最大耐力の約 $80 \%$ 時）

(a) $L C(2.5$ tonf $)$

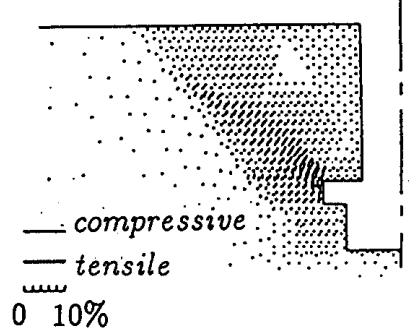

(b) $M C(4$. tonf $)$

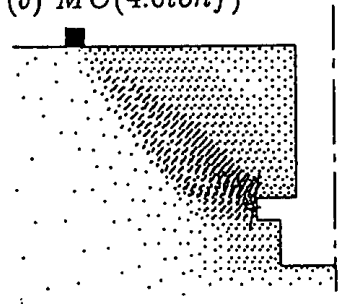

(c) $N C(5.0 \operatorname{ton} f)$

図一15 主ひずみ分布 (最大耐力の約 $80 \%$ 時)

ひび割れが反カリング内径位置に達したものであり， NC の場合にはおおよそコーン内部のひび割れの両端を それぞれ定着プレート外周と反カリング内周に結んだも のであった。

図一14に，解析における最大耐力の約 $80 \%$ 加力時の ひび割れの進展状況を示す。解析では，分布ひび割れモ デルを用いたのでひび割れは要素領域にわたって表さ れ, 実験時に観察された複雑なひび割れパターンを明確 に表現することはできない。そこで図一15に示した同 じ荷重レベルでの主ひずみ図における引張ひずみからひ び割れパターンを決定すると，(a) の LCでは, 定着 プレートから引抜き面に対してほぼ平行に進むひび割れ

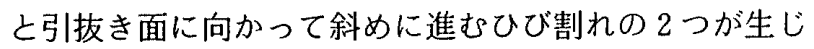
ていることがわかる。平行に進むひび割れは実験では確 認されないが, ひび割れ幅の大きい斜めに進むひび割れ
の発生位置や進展状況はよく一致している。

(b), (c) 図の MC や NCでは，1 次，2次ひび割れ が明確に分離されている。また，これらのひび割れが， 反カリング近傍の 3 軸圧縮ひずみ領域に達して停止する ことを示している。コーン内部のひび割れは,この荷重 レベルでは，顕著に表れていないことがわかる。このよ うなひび割れパターンは, Krenchel の行った奏験（コー ン頂角 $\left.\alpha=62^{\circ}\right)^{15\rangle}$ でも確認されており，特に 2 次的に生 じるひび割れは無数のマイクロクラックであり最大耐力 以降まで大きく開くことはないとしている。

図一16に, 解析における最大耐力時の主ひずみ分布 を示す。また，図一17に，この時の引張主ひずみを等 高線で示す。(a) 図の LC の場合, 図-15 (a) と比べ て相対的に斜め方向のひび割れ位置の引張ひずみが拡大 し、このひび割れがコーン状破壊面を形成することがわ 
(a) $L C$

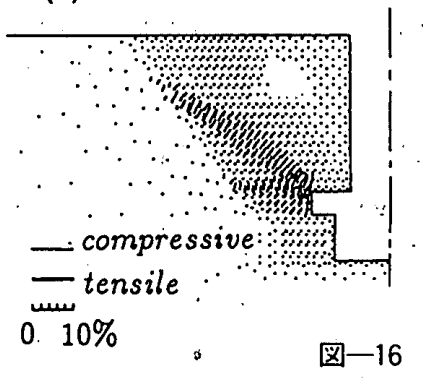

(b) $M C$

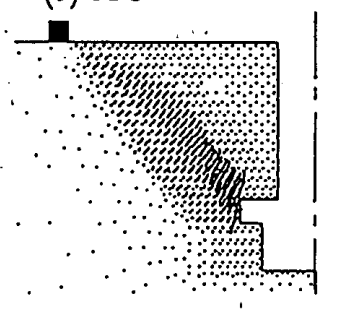

(c) $N C$

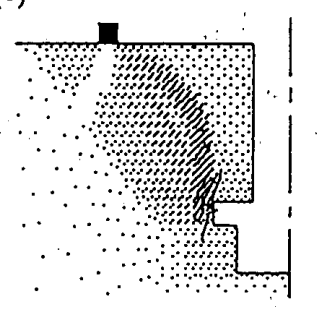

(a) $L C$

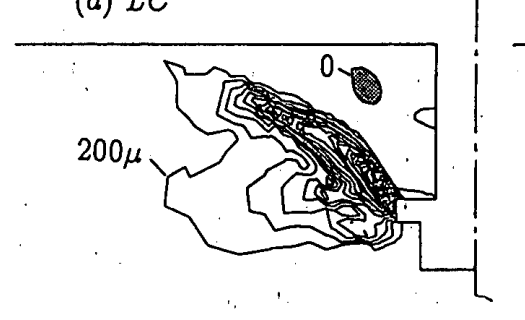

(b) $M$

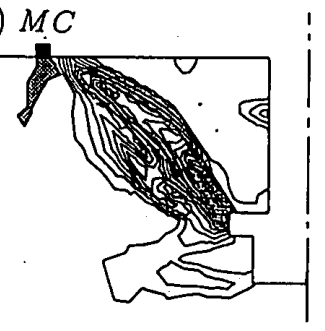

(c) $N C$

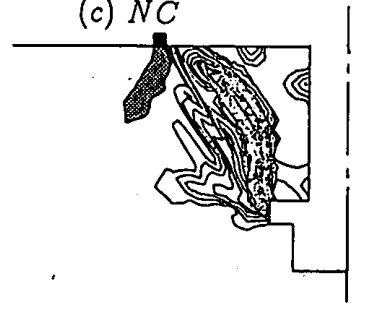

图一17 引張主ひずみの等高線図

(b) $M C$ (c) $N C$
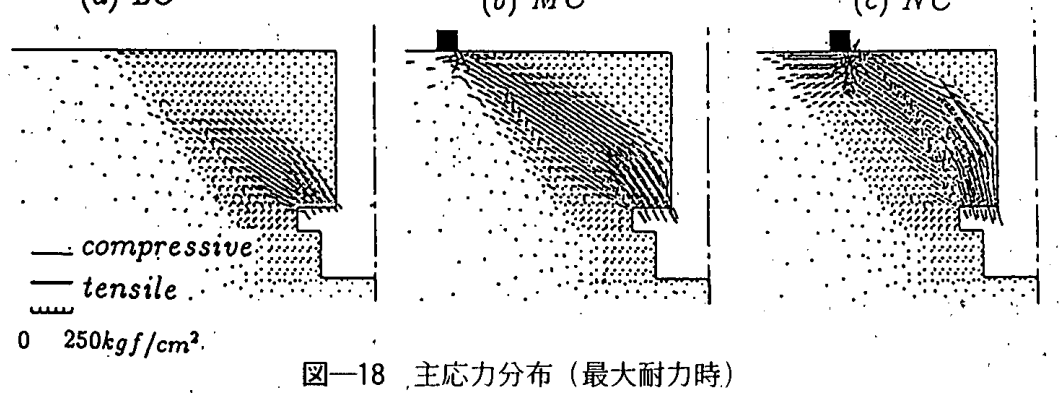

かる。(b) 図の MC では, コーン内部で引張ひずみの 増大が顕著で 2 次びび割れが反カリングの内径位置にま で到達し, 実験で観察された内側に凹の破壊面を形成し ている。また、コーン内部ひび割れは解析では明確に表 れていないが 2 次ひび割れから徐々にひび割れ発生域が コーン内部に広がっていき, 実験で観察されたひび割れ 発生域にまで達している。(c) 図の NCでは, 引張ひ ずみがコーン内部のひび割れに集中して破壊面を形成す るのが明確に表れている。定着プレートと内部ひび割れ を結んだ破壊面はほぼボルト軸に平行であり，そこでの ひずみ状態は引張だけでなく圧縮側も顕著に表れている のが特徴である。

\section{6. コーン状破壊の耐荷機構}

以上の解析結果を実験結果と比較して検討した結果, 解析は十分な精度でコーン状破壊を再現していると考え られる。ここでは, 解析結果から得られた応力状態から コーン状破壊の耐荷機構について考察を行う。

最大耐力時の内部の主応力状態を図一18に示す。(a) 図のLCではコーン破壊面の形状をほとんど主玨縮応 力方向と一致していて, その王縮応力も破壊面上ではそ れほよ゙大きくはなっていないことがわかる。(b) 図の
MCにおいては, 定着プレート近傍で主圧縮応力の方 向の急激に変化するのがみられるが; その他の破壊面で は主応力の方向と破壊面の方向とが一致している。それ に対し（c）図のNCでは，コーン状破壊面に沿ってひ び割れ面でのせん断伝達が卓越し引張応力が顥著に表れ ている。また，定着プレート直下のボルト軸に平行な破 壊面では圧縮応力がひび割れたコンクリートの最大強度 に達し圧縮破壊を生じている。このことから，NCの場 合と同じ頂角をもつ引抜き試験において，引抜き耐力と コンクリートの圧縮強度が良く対応し，コンクリリトの 粗骨材量の変化により引抜き耐力が影響を受けるという 実験結果を説明できる。

\section{7. 解析上の問題点と今後の課題}

本解析で用いたひび割れのモデルでは，ひび割れ面で せん断応力とともに伝達する圧縮直応力を表現していな いので, 図一18の主応力図では,ひび割れ面で伝達さ れるせん断応力が引張強度を超過するような引張主応力 を生じさせている。この圧縮応力は，NCのように破壊 面が引抜きボルト軸に平行に近い場合にはコーン内部に リング圧縮応力を生じさせ半径方向のひび割れを制御 し，LCのように引拢き面に平行な場合にはコーン状破 
壊面の形成を早める方向にあると考えられる。また，ひ び割れの方向をひずみ履歴に対して固定したため応力分 布に乱れが生じている。より正確な応力状況・破壊性状 を再現するには，LCのような場合には，ひび割れ面で のせん断伝達を精度よく表現した離散ひび割れモデルを 用いた解析を行う必要があると考えられる。逆にひび割 れ面が開かず，マイクロクラックでとどまって耐荷機構 を形成する $\mathrm{MC} ゃ \mathrm{NC}$ の場合には, 離散ひび割れモデ ルよりはひび割れをコンクリートの領域で表現した分布 ひび割れモデルが適しているといえる。NCゃ MC の 解析結果が LC の場合より実駼結果をよりよく表現し ているのは，この特性を反映しているためである。

\section{8. 結 論}

引張力を受けるアンカーボルトのコーン状破壊機構を 実験および有限要素解析によって検討した。その結果は, 次のように要約される。

（1）コーン状破壊は，反力の作用位置によって破壊機 構が異なり, 反力位置をボルトに近づけると最大耐力は 大きくなる。本研究で行った解析により, 反力位置が最 大耐力に与える影響をよく表現することができた。

（2）反力の位置が破壊コーンの形状に影響を与えない ほどボルトから離れている場合には単一のコーン状破壊 面が引張応力により形成され, 反力位置が近い場合には 2 次ひび割れ, 内部ひび割れとコーン内部にひび割れが 順次発生し, 最終の破壊面がこの内部ひび割れを縫うよ うにせん断滑り面を生じて形成される。この耐力機構は, 実験之解析の結果の比較から明確にすることができた。 （3）構造体コンクリートの強度試験である引抜き試験 と同じ円錐台頂角 $\alpha=67^{\circ}$ の場合には，定着プレートと 反力位置を直接結ぶコンクリートの圧縮束が内部ひび割 れ間に影著に形成され，最大耐力はコンクリートの圧縮 束の圧縮破壊を伴うスリップ破壊時に発揮される。その 最大耐力の大きさは, コンクリートの圧縮束の強度とそ の時にコーン内部のひび割れを伝達しているせん断力に より決定される。したがって, コンクリートの圧縮強度 に強く依存することになる。

（4）モルタルのように骨材の缾み合いによるひび割れ 面でのせん断伝達が期待できない場合には，ここで用い た解析手法ではその破壊機構を説明することはできな い。このような場合には，応力によるひび割れ進展の判 定に限界があり，ひび割れ進展をエネルギーバランスか ら追跡する破壊力学的手法が有効であると考えられる。

\section{参考文献}

1）日本建築学会：各種合成構造設計指針，1985 年 2 月

2) ACI-349-76: Code requirements for nuclear safety related concrete structures, ACI journal, Aug. 1979

3) Malhotra, V.M. : Evaluation of the Pull-out Test to determine Strength of In-Situ Concrete, Research and Testing (RILEM, Paris) Vol.8, No.43, Jan.-Feb., 1975

4）森田司郎, 小松勇二郎：構造体コンクリート強度管理へ の引抜き試験法の応用, コンクリート工学協会コンクリー トの非破壊試験法に関するシンボジウム論文集, 平成 3 年 4 月

5) Ottosen, N.S. : Nonlinear Finite Element Analysis of Pull-Out Test, Journal of Structural Div., ASCE, Vol. 107, No. ST4, April, 1981

6) Stone, W. C. and Carino, N. J. : Comparison of Analytical with Experimental Internal Strain Distributions for the Pullout Test, ACI Journal, Proceedings, Vol.81, No. 1, Jan. -Feb. 1984

7）森田司郎, 小松勇二郎, 近藤吾郎：引抜き試験によるコ ンクリート推定強度への諸要因の影響( コーン寸法, 乾燥, 粗骨材量の影響)，セメント技術年報，No. 37，1983

8) Gerstle, K. H. : Simple Formulation of Triaxial Concrete Behavior, ACI Journal, Vol.78, No. 5, Sep. -Oct. 1981

9) Sargin, M. : Stress-Strain Relationships for Concrete and Analysis of Structural Concrete Sections, Study No. 4, Solid Mechanics Division, University of Waterloo, Canada, 1971

10) Ottosen, N.S. : A Failure Criterion for Concrete, Journal of Eng. Mec. Div. ASCE, Vol. 103, EM4, Aug. 1977

11) Schickert, G. and Winkler, H. : Versuchsergebnissezur Festigkeit von Beton bei mehraxialer Druckbeanspruchung, DAfStb Heft 277, Wilhekm Ernst \& Sohn, Berlin, 1977

12) Vecchio, F. and Collins, M. P. : The Response of Reinforced Concrete to In-Plane Shear and Normal Stress, Publication No. 82-03, Dept. of Civil Eng. Univ. of Toront, March 1982

13) Bazant, 2.P. : Mechanics of Distributed Cracking Appl. Mech. Rev. Vol. 39, No. 5, May 1986

14）松藤泰典, 河村博之, 佐治泰次：コンクリートに定着さ れた鉄筋の引抜き強度に関する研究（コンクリートが破 壊する場合), 九州大学工学集報, 第 44 巻第 6 号, 昭和 46 年 12 月

15) Krenchel, H. and Shah, S.P. : Fracture analysis of the pullout test, Matériaux et Constructions, Vol.18, No. 108,1985

(1991 年 8 月 21 日原稿受理, 1992 年 2 月 12 日採用決定) 